\section{Screening Exotic Firs for the Midwestern United States: Interspecific Variation in Adaptive Traits}

\author{
G.E. Jones \\ Department of Horticulture, Michigan State University, East Lansing, \\ MI 48824 \\ B.M. Cregg ${ }^{1}$ \\ Department of Horticulture and Department of Forestry, Michigan State \\ University, East Lansing, MI 48824
}

Additional index words. cold hardiness, budbreak, drought tolerance, carbon isotope discrimination, foliar nutrition, soil chemistry

\begin{abstract}
Conifers represent a sizeable portion of nursery and landscape sales in the upper midwestern U.S. Several conifer species have been overplanted to the point where disease problems and insect pressures have developed. Although more than 40 true fir (Abies Mill.) exist throughout the northern hemisphere, use of firs in the landscape and Christmas tree industry has been limited to relatively few species. This is largely due to perceived intolerance of many site conditions. However, recent research suggests Abies are more tolerant of varying site conditions than originally thought. Successful introduction of new exotic fir species for landscape use will require a systematic approach to identify species that are adapted to environmental stresses. In this article we review the extent and nature of inter-specific variation among Abies species in traits commonly associated with tolerance of stresses found in the upper midwestern U.S. Specifically, we focus on cold hardiness, budbreak, photosynthetic gas exchange and water relations, and response to soil $\mathrm{pH}$. It is important to match plants possessing necessary adaptive characteristics with the existing site conditions. Therefore, multiple screening factors should be met when identifying species or trees from different provenances for future introduction.
\end{abstract}

The upper midwestern U.S. includes the states surrounding the Great Lakes (zones 3 to 6) [U.S. Department of Agriculture (USDA), 1990]. This region has a large nursery industry, of which conifers represent a sizable portion. In the year 2000, coniferous trees produced in the upper midwestern U.S. resulted in sales of more than \$119 million (USDA, 2001). Colorado blue spruce (Picea pungens var. glauca Engelm.), norway spruce [Picea abies (L.) Karstens], white pine (Pinus strobus L.), and douglas fir [Pseudotsuga menziesii (Mirb.) Franco] are used extensively in the midwestern landscape, often to the point of overplanting. This lack of diversity has resulted in increased disease problems and insect pressures ( $\mathrm{Mc}$ Cullough et al., 1998, 1999).

True firs (Abies spp. Mill.) are generally underutilized in landscapes. In general, Abies prefer cool, moist, well-drained sites with acidic soil. In the Christmas tree industry, the use of Abies has been primarily limited to $A$. fraseri (Pursh) Poir. and A. balsamea (L.) Mill. grown in the eastern U.S., while $A$. grandis (Dougl. ex D.Don) Lindl., A. nordmanniana (Steven) Spach, and $A$. procera Rehder. are grown in the Pacific northwestern U.S.; although, other species have been grown to a lesser extent. In cooler regions of the eastern U.S., A. concolor (Gord. et Glend.) Lindl. Ex Hilderbr. is com-

Received for publication 9 Nov. 2005. Accepted for publication 4 Jan. 2006

${ }^{1}$ To whom reprint requests should be addressed; e-mail cregg@msu.edu. monly planted in the landscape. However, the use of additional species and varieties has been limited due to their perceived intolerance to suboptimal site conditions.

Abies species are found in the northern hemisphere at higher latitudes or at lower latitudes at higher elevations. In their natural habitat, Abies are considered late-successional trees (Kohyama, 1984) as they are not among one of the first plant communities that successfully colonizes disturbed sites. Rather, they are generally slow growing and shade tolerant replacing pioneer species as shade levels increase. The number of Abies species has been debated, reportedly ranging from 39 (Liu, 1971) to 46 (Farjon, 1990) to 55 (Rushforth, 1987). Farjon(1990) clustered the species into 10 sections based on cone characteristics, flower color, needle structure, pollen grains, geography, and fossil records. Abies naturally hybridize easily within and between sections (Liu, 1971) where native ranges overlap (Isoda et al., 2000). Hybrids often display increased vigor (Klaehn and Winieski, 1962). Crichfield (1988), however, suggests that artificial crosses between sections are more difficult than crosses within sections.

Abies have been fragmented by glaciation and have adapted to a wide range of site conditions. As a result, species ranges vary greatly. Abies nebrodensis (Lojac.) Mattei., for example, consists of only several dozen trees spread over a few square kilometers in Italy (Parducci et al., 2001). In contrast, the range of $A$. sibirica Ledeb. stretches for thousands of hectares. Species such as A. balsamea and $A$. fraseri are thought to be closely related but isolated due to past glaciation (Jacobs et al., 1984; Myers and Bormann, 1963). Langlet (1963) hypothesized large species distribution ranges increase the likelihood of genetic adaptation to diverse environmental factors. This suggests adaptive traits may vary more in species with large geographic distributions than species with narrow ranges.

In the upper midwestern U.S., winter temperatures, moisture, and soil $\mathrm{pH}$ vary greatly. During winter, average annual low temperatures range from -20 to $-45^{\circ} \mathrm{C}$ in some areas (USDA, 1990). The date of the last spring frost can vary considerably. In the lower peninsula of Michigan, the latest spring frost ranged from late May in the south to early June in the north (Illinois Department of Natural Resources, 2005). In the summer, monthly rainfall deficits (potential evapotranspiration-precipitation) average up to $4.0 \mathrm{~cm}$ in some regions of the upper midwestern U.S. (White and Host, 2002). Months with $<2.5 \mathrm{~cm}$ of rainfall can occur in most past of midwestern U.S. during the summer (Illinois Department of Natural Resources, 2005). In the upper midwestern U.S., soil $\mathrm{pH}$ levels vary greatly from more acidic (3.6 to 4.4) in coniferous forests to more alkaline (6.1 to 7.8) in grassland regions (USDA, 1996, 2003). Identifying Abies species that are tolerant of environmental stresses can provide an opportunity to diversity the choice of conifers for landscape use.

Historically, plant introductions have been based on anecdotal reports from arboreta or botanical gardens. Characterizing differences in adaptive characteristics can provide baseline information for a more systematic approach to screen future Abies introductions. The following review will focus on the different adaptive characteristics that are important to future $A$ bies introductions and screening efforts in the upper midwestern U.S. with respect to temperature, water relations, and soil $\mathrm{pH}$.

\section{Temperature}

In the upper midwestern U.S., average winter low temperatures can reach $-45^{\circ} \mathrm{C}$ and spring frost can occur as late as early June. Tolerance to extreme cold temperature and late spring frosts is an important adaptive characteristic for future species introductions.

Cold hardiness. In the landscape and Christmas tree industries, cold hardiness is an important requirement for quality trees. Cold hardiness develops as trees pass through the following three stages: 1) short days causing cessation of growth, 2) freezing temperatures resulting in a metabolic reorganization of macromolecules resistant to severe dehydration, and 3 ) increasing cold hardiness through dehydration resistance or supercooling (Weisner, 1970). When days become shorter and temperatures drop in the fall, trees accumulate sugars and starches in their cells, lowering their freezing point (Sutinen et al., 2001; Weisner, 1970). Trees reach their maximum cold hardiness in midwinter and then gradually become less cold hardy as temperatures warm in the 


\begin{tabular}{|c|c|c|}
\hline Species & $\begin{array}{c}\text { Cold } \\
\text { hardiness } \\
\left({ }^{\circ} \mathrm{C}\right)\end{array}$ & Source \\
\hline amabilis & $<-40$ & Coleman et al., 1992 \\
\hline balsamea & -70 & Sakai, 1982 \\
\hline balsamea var phanerolepis & $<-44$ & Jones and Cregg, 2006 \\
\hline firma & -30 & Sakai, 1982 \\
\hline homolepis & -40 & Sakai, 1982 \\
\hline koreana & -70 & Sakai, 1982 \\
\hline lasiocarpa & -60 & Gordon-Kamm, 1980 \\
\hline lasiocarpa & $<-40$ & Coleman et al., 1992 \\
\hline nephrolepis & $<-44$ & Jones and Cregg, 2006 \\
\hline procera & -70 & Sakai, 1982 \\
\hline sachalinensis & -70 & Sakai, 1982 \\
\hline sibirica & -70 & Sakai, 1982 \\
\hline spectabilis & -25 & Sakai, 1982 \\
\hline veitchii & -70 & Sakai, 1982 \\
\hline
\end{tabular}

spring (Ritchie, 2003). In late winter and early spring, periods of warmer temperatures are commonly followed by periods of colder temperatures in the upper midwestern U.S. Species can regain cold hardiness when colder temperatures return; however, cold hardiness is still lost more quickly than it is regained (Strimbeck et al., 1995). Temperature fluctuation in the spring can lead to late winter injury and damage to buds, needles, roots, and cambial tissue (van der Kamp and Worrall, 1990).

Conditioning to low temperatures affects the physiological responses to temperature extremes. Abies procera seedlings exposed to high temperatures $\left(24\right.$ to $\left.35^{\circ} \mathrm{C}\right)$ experienced more damage when exposed to subfreezing temperatures than seedlings grown at warm (18 to $\left.27^{\circ} \mathrm{C}\right)$ or cool $\left(12\right.$ to $\left.19^{\circ} \mathrm{C}\right)$ temperatures (Owston and Kozlowski, 1981). Branches of field-grown A. lasiocarpa (Hook.) Nutt. were cold hardy to temperatures below -60 ${ }^{\circ} \mathrm{C}$ in midwinter. Branches from the same tree exposed to $20^{\circ} \mathrm{C}$ for $132 \mathrm{~h}$ were cold hardy only to temperatures near $-20{ }^{\circ} \mathrm{C}$ (GordonKamm, 1980).

Cold hardiness varies greatly among species (Table 1) and is dependent upon the climate and geography of a species native range. In cold regions, the amount of snow cover can influence the cold hardiness of species and provenances. In regions receiving heavy snowfall, snow can keep needle temperatures near $0{ }^{\circ} \mathrm{C}$ and prevent plants from acclimating to colder conditions. Abies sachalinensis (Fr. Schmidt) Mast. grown in areas with heavy snow cover were more prone to frost injury than provenances grown in areas with less snow cover (Eiga and Sakai, 1987).

Abies adapt to different temperature extremes found in their native ranges and cold hardiness increases in species and provenance native to higher latitudes. Abies spectabilis (D. Don) Spach, native to Nepal $\left(26\right.$ to $\left.38^{\circ} \mathrm{N}\right)$, is cold hardy to $-25^{\circ} \mathrm{C}$ while $A$. balsamea, native to Canada ( 38 to $\left.59^{\circ} \mathrm{N}\right)$ and $A$. sibirica, native to Siberia $\left(42\right.$ to $\left.67^{\circ} \mathrm{N}\right)$, are cold hardy to $-70{ }^{\circ} \mathrm{C}$ (Liu, 1971 ; Sakai, 1982). Christmas tree growers found $A$. fraseri, native to North Carolina $\left(35\right.$ to $\left.37^{\circ} \mathrm{N}\right)$, and $A$. concolor, native to the Rocky Mountains $\left(30\right.$ to $\left.44^{\circ} \mathrm{N}\right)$, were less cold hardy than $A$. balsamea $\left(38\right.$ to $\left.59^{\circ} \mathrm{N}\right)$ (Liu, 1971; Nicholls and Palmer, 1985). Likewise, varying levels of cold hardiness are also found within species.

Relationships between elevation and cold hardiness are often similar to latitudinal effects. Species and trees from provenances from higher elevations are more cold hardy than species and trees from lower elevations. In dry air, temperatures cool at the adiabatic lapse rate of $3{ }^{\circ} \mathrm{C}$ per $300 \mathrm{~m}$ increase in elevation. Abies sachalinensis is native to the Hokkaido hardiness increases as elevation increases (Eiga and Sakai, 1984). In British Columbia, provenances tests showed $A$. grandis from coastal provenances were more susceptible to frost damage than trees from colder, inland provenances (Xie and Ying, 1993).

In addition to midwinter cold hardiness, understanding budbreak patterns is important since species that resume growth prior to the last winter frost are often damaged. A chilling requirement and a thermal time requirement exist during winter that restrict tree growth (Campbell and Sugano, 1979; Howe et al., 2003). Cold hardiness can be lost and growth can occur once the thermal time requirement is met (Gordon-Kamm, 1980; Perry and Wu, 1960). Once the temperature threshold specific to that species has been met, growing degree days (GDD) begin to accumulate. Growing degree days are used to quantify the duration of temperatures above a threshold specific to the species.

In Abies, GDD are used to track budbreak. Species growing at higher elevations are exposed to fewer warm days. If the GDD requirement were the same for all trees, then trees at higher elevations would theoretically take longer to surpass their GDD requirement than trees at lower elevations or coastal regions. In response, trees grown at higher elevations have a reduced GDD requirement and break bud only after sufficient warming has occurred. For example, Worrall (1983) found A. lasiocarpa growing at high elevations have a lower temperature threshold than trees growing at lower elevations or coastal areas, suggesting adaptation to a shorter growing season.

In provenance tests and species trials, trees are often grown in areas with climates different from their native regions, which can affect budbreak. Abies amabilis Dougl. ex Forbes broke bud later than $A$. lasiocarpa when grown at the same location, indicating differences in islands in Japan where their maximum cold their GDD requirement for bud break (Worrall, 1983). In Northern Europe provenance trials, A. lasiocarpa from northern latitude provenances broke bud earlier than trees from low- and midlatitude provenances (Hansen et al., 2004). Similarly, Abies alba Mill. from northern latitudes broke bud earlier than lowlatitude trees (Hansen and Larsen, 2004). In Ohio provenance trails, A. balsamea from New York and Pennsylvania and $A$. fraseri from North Carolina broke bud earlier and had more frost damage than A. balsamea var. phanerolepis (Fern.) Lui from West Virginia, which broke bud later (Brown, 1983). In European provenance trials, A. alba from Bavaria, Germany broke bud earlier than $A$. grandis trees from inland and coastal provenances (Scholz and Stephan, 1982). When grown at the same site, $A$. grandis from provenances with early budbreak had increased late spring frost damage; although, trees from inland provenances showed less damage than trees from coastal provenances (Scholz and Stephan, 1982). Abies species with increased midwinter cold hardiness break bud earlier than less cold hardy species when grown at the same location (Jones and Cregg, 2006).

In summary, low winter temperatures make adequate cold hardiness necessary for survival of Abies in the upper midwestern U.S. In selecting new Abies species for introduction with necessary cold hardiness, collection efforts should focus on species and trees from northern latitude and higher elevation provenances. Increased snow cover can insulate trees and limit the development of cold hardiness, so seed collection should focus on regions with relatively low winter snowfall. Species and trees from provenances that break bud early are at increased risk of late spring frost damage which damages tree form and aesthetics. Late budbreak is necessary in species selected for introduction in the upper midwestern U.S. Trade-offs exist between midwinter cold hardiness and date of budbreak making selection of species with adequate cold hardiness and late budbreak necessary.

\section{Water Relations}

In the upper midwestern U.S., periods of water stress are common throughout the growing season and can limit tree survival and growth. Identifying species capable of tolerating drought conditions is an important criterion for future species introduction to the landscape and Christmas tree industries.

Drought tolerance. Abies respond to both soil and atmospheric drought. Numerous studies have demonstrated species and provenance variation in growth and survival response to drought (Cregg, 2004). Drought reduced the number of shoot internodes and internode elongation in A. magnifica A. Murr. and A. concolor (Hallgren and Helms, 1998). In Switzerland, $A$. alba shed needles in response to drought conditions (Webster etal., 1996). Abies grandis from inland and higher elevation provenances survived planned dry-down treatments better than trees from coastal provenances (Scholz and Stephan, 1982). This suggests trees from 
inland provenances are more drought tolerant than coastal provenances.

Drought effects on survival and growth are ultimately linked to physiological responses. Stomata regulate water lost during transpiration and are particularly important as humidity decreases. At low humidity, the water vapor pressure deficit increases and results in more plant water loss if not regulated. Increases in water vapor pressure deficit reduced photosynthetic gain in $A$. nordmanniana (Guehl et al., 1989). Stomatal conductance decreases as humidity decreases and results in lower photosynthetic rates in several Mediterranean Abies species (Guehl et al., 1991). Stomatal response to increased water vapor pressure deficits was delayed in $A$. alba and resulted in excess transpiration loss and eventually decreased photosynthetic gain. However, A. alba from drier regions maintained photosynthesis better under soil moisture and water vapor pressure deficits than trees from maritime regions (Guehl and Aussenac, 1987).

Species also respond differently to dry soil conditions. In A. bornmulleriana Mattf., stomata closed quickly and the photosynthetic rate was reduced at low soil water potentials. Under the same soil conditions, $A$. cephalonica Loud. exhibited a higher photosynthetic rate than A. bornmulleriana. Guehl et al. (1991) suggest $A$. bornmulleriana adapts to avoid internal water deficits while $A$. cephalonica adapts to tolerate drought.

In cold, snowy regions, lower temperatures can reduce moisture stress. During winter and spring months, colder temperatures increase snowfall, limit snowmelt, and improve summer soil-moisture levels at higher elevations. Adequate snowfall improved summer soil moisture levels and increased growth in $A$. lasiocarpa. Furthermore, cooler temperatures reduce evapotranspiration in the summer and reduce moisture stress in A. lasiocarpa (Peterson et al., 2002). As a consequence, selection of Abies for drier regions should focus on species native to dry regions with warm temperatures throughout the growing season.

Water use efficiency and Carbon isotope discrimination. Two common methods of quantifying drought tolerance are instantaneous water use efficiency (WUE) and carbon isotope discrimination $(\Delta)$. Water use efficiency (WUE) is calculated as the amount of $\mathrm{CO}_{2}$ fixed (net photosynthesis) per unit of water lost (needle conductance) and is often used to compare drought tolerance among species or provenances. The relationship between net photosynthesis and needle conductance is curvilinear with net photosynthesis initially declining more slowly than the decline in needle conductance (Cregg, 1994). Other factors being equal, high WUE indicates better drought tolerance. When adequately watered, container grown $A$. alba from southern Italy (warmer, drier regions) maintained higher photosynthesis in 1- and 2-year-old needles than trees from central and eastern Europe (cooler, wetter regions) in which 2-year-old needles declined in photosynthetic gain (Larsen and Mekic, 1991). This resulted in higher WUE in the trees from southern Italy indicating increased drought tolerance.
Carbon isotope discrimination $(\Delta)$ is a measure of water use efficiency across the course of the growing season and may be used to investigate WUE and drought stress. $\mathrm{C}_{3}$ plants, which include conifers, discriminate against ${ }^{13} \mathrm{C}$ while fixing carbon and thus have a lower ratio of ${ }^{13} \mathrm{C} /{ }^{12} \mathrm{C}\left(\delta^{13} \mathrm{C}\right)$ than the atmosphere (Farquhar et al., 1989). However, as stomata close, intercellular $\mathrm{CO}_{2}$ levels decline due to photosynthetic assimilation. As a result, discrimination against ${ }^{13} \mathrm{C}$ decreases resulting in a higher $\delta^{13} \mathrm{C}$ ratio. Tissues with lower $\Delta$ (higher $\delta^{13} \mathrm{C}$ ) values indicate periods of reduced stomatal conductance. Both theoretical and empirical studies have linked increased water use efficiency with reduced $\Delta$ (Farquhar et al., 1989; Masle and Farquhar, 1988).

Several studies have documented environmental response of $\Delta$ in Abies. In $A$. spectabilis, increased relative humidity and precipitation were positively correlated with $\Delta$ in tree rings (Xiaohong et al., 2003). Similarly Guehl et al. (1991) showed $\Delta$ increased due to more conductance with increased rainfall. Other environmental factors such as pollution reduced stomatal conductance and lowered $\Delta$ values in tree rings of $A$. firma Sieb. et Zucc. (Sakata and Suzuki, 2000).

Grouping species into sections and subsections could help select species with low $\Delta$ (high WUE) for future evaluations. Carbon isotope discrimination $(\Delta)$ has been shown to vary among species (Table 2 ). When species are combined into species sections and subsections, the Medianae subsection of Balsamea includes species with low $\Delta$ (higher WUE); although, trees from different provenances presumably differ within a species as evident in provenance trials including $A$. alba and A. grandis (Larsen and Mekic, 1991; Scholz and Stephan, 1982). Recently, much interest has focused on creating hybrid crosses. These crosses have showed signs of hybrid vigor (Klaehn and Winieski, 1962); although, high $\Delta$ (low WUE) suggests this vigor may come at a cost to drought tolerance. Future hybrid crosses should be closely evaluated to select for hybrid vigor and drought tolerance.

In the mountainous areas of the western U.S., precipitation patterns can vary greatly. Alexander et al. (1990) describe the native range of $A$. lasiocarpa to include regions receiving less precipitation than $A$. magnifica (Laacke, 1990a) and A. procera (Franklin, 1990) and more precipitation than A. concolor (Laacke, 1990b) and A. grandis (Foiles et al., 1990). Instantaneous WUE measurements in A. lasiocarpa were higher early and late in the day than another subalpine conifer, Pinus albicaulis Engelm., which shares a similar native range; however, WUE levels declined and were lower than P. albicaulis at midday. Conversely, needles from the previous year show $A$. lasiocarpa had a higher $\Delta$ than $P$. albicaulis and thus a lower WUE over time (Sala et al., 2001). When compared to five other conifers native to the northern Rocky Mountains, $\Delta$ was significantly higher (lower WUE) in A. lasiocarpa (Piñol and Sala, 2000) suggesting that while A. lasiocarpa may be moderately drought tolerant among other Abies species in the western U.S.; it still less tolerant of dry sites when compared to other conifers sharing its native range.

In summary, drought tolerance and water use efficiency are necessary for future species introductions in the upper midwestern U.S. Using taxonomic classification of Abies sections and subsections may be helpful in selecting species with increased water use efficiency (low $\Delta$ ). Trees should be selected from inland seed sources and regions with warm, dry climates for increased drought tolerance. Care should be taken to not compromise other adaptive characteristics such as cold hardiness for the sake of increased drought tolerance.

\section{Soil Nutrition}

Plant nutrition is critical to physiological processes. Even if soil nutrient levels are high, the availability of these nutrients may be influenced by soil pH (Lucas and Davis, 1961). In A. balsamea grown in New Hampshire, little correlation existed between soil and foliar nutrient levels, suggesting that another factor such as soil $\mathrm{pH}$ influenced nutrient availability (Bruns, 1973). Therefore, identifying ideal soil $\mathrm{pH}$ and nutrient ranges of Abies species and matching them to the site is necessary in future plant introductions to the landscape and Christmas tree industries.

Nutrition. Decreasing soil $\mathrm{pH}$ levels tend to increase the $\mathrm{Mn}, \mathrm{Fe}, \mathrm{Mg}$, and $\mathrm{P}$ that is available

Table 2. Reported carbon isotope discrimination $(\Delta)$ for several Abies species and hybrids.

\begin{tabular}{|c|c|c|c|c|}
\hline Species & Section $^{z}$ & Subsection $^{z}$ & $\Delta$ & Source \\
\hline firma & Momi & Firmae & $13.80^{x}$ & Sakata and Suzuki, 2000 \\
\hline bornmulleriana & Abies & & $14.31^{x}$ & Guehl et al., 1991 \\
\hline balsamea & Balsamea & Laterales & $18.80^{\mathrm{y}}$ & Jones, 2005 \\
\hline koreana & Balsamea & Medianae & $18.86^{\mathrm{y}}$ & Jones, 2005 \\
\hline veitchii & Balsamea & Medianae & $19.00^{y}$ & Jones, 2005 \\
\hline fraseri & Balsamea & Medianae & $19.05^{y}$ & Jones, 2005 \\
\hline holophylla & Momi & Holophyllae & $19.11^{\mathrm{y}}$ & Jones, 2005 \\
\hline nephrolepis & Balsamea & Medianae & $19.24^{y}$ & Jones, 2005 \\
\hline amabilis & Amabilis & & $19.32^{y}$ & Buchmann et al., 1998 \\
\hline koreana $\times$ balsamea & Hybrid & & $19.43^{y}$ & Jones, 2005 \\
\hline lasiocarpa var. arizonica & Balsamea & Laterales & $19.58^{y}$ & Jones, 2005 \\
\hline koreana $\times$ veitchii & Hybrid & & $19.77^{y}$ & Jones, 2005 \\
\hline fraseri $\times$ homolepis & Hybrid & & $20.04^{y}$ & Jones, 2005 \\
\hline lasiocarpa & Balsamea & Laterales & $20.75^{y}$ & Piñol and Sala, 2000 \\
\hline
\end{tabular}

${ }^{\mathrm{z} A c c o r d i n g}$ to Farjon, 1990.

${ }^{\mathrm{y}}$ Foliar ${ }^{13} \mathrm{C}$ analysis.

${ }^{\mathrm{x}}$ Growth ring ${ }^{13} \mathrm{C}$ analysis. 
to the tree (Lucas and Davis, 1961). Increasing soil $\mathrm{pH}$ in $A$. alba led to Mn deficiencies and needle chlorosis ultimately resulting in tree decline (Hiltbrunner and Flückiger, 1996). In several Abies species, photosynthetic efficiency and foliar $\mathrm{Mn}, \mathrm{B}, \mathrm{K}, \mathrm{Zn}$, and $\mathrm{Cu}$ levels declined with increased soil $\mathrm{pH}$ levels (Cregg et al., 2004). Decreasing levels of these nutrients were also strongly correlated with a fluorescence $\left(\mathrm{F}_{\mathrm{v}} / \mathrm{F}_{\mathrm{m}}\right)$ ratio and decreased chlorophyll concentration in the needles.

Nitrogen, $\mathrm{Mg}, \mathrm{Mn}$, and $\mathrm{Cu}$ are several nutrients that are important to the photosynthetic process. In A. fraseri, higher foliar $\mathrm{N}$ and $\mathrm{P}$ levels were characteristic of increased visual quality while higher foliar $\mathrm{Ca}, \mathrm{Mg}$, and $\mathrm{Fe}$ quality. In the same study, foliar nutrient ratios $\mathrm{Mg}$, and $\mathrm{P}$ to $\mathrm{Fe}$ ) were important indicators of increased visual quality in $A$. fraseri (Rothstein and Lisuzzo, 2003). Needle chlorosis developed in A. nordmanniana with decreased foliar Fe, Mg, Mn, N, and S levels (Khalil et al., 1989). However, other site factors such as shade can influence foliar nutrient levels. Foliar P and Ca levels were highly variable decreased variable fluorescence to maximum levels were found in trees with lower visual (e.g., $\mathrm{N}$ to $\mathrm{Ca}, \mathrm{N}$ to $\mathrm{Mg}, \mathrm{N}$ to $\mathrm{Fe}, \mathrm{P}$ to $\mathrm{Ca}, \mathrm{P}$ to

in $A$. grandis, possibly in response to shade conditions (Moore et al., 2004). Chlorophyll concentration increased following NPK fertilization in A. balsamea (Lavigne et al., 2001). In A. balsamea var. phanerolepis Fern. N, K, and $\mathrm{Ca}$ foliar nutrient levels were significantly correlated with tree height and needle length (Brown, 2000).

The efficiency by which photosystem II captures light may be expressed as the ratio of variable fluorescence to maximum fluorescence $\left(\mathrm{F}_{\mathrm{v}} / \mathrm{F}_{\mathrm{m}}\right)$ (Bjorkman and Demming, 1987) and may be used to compare plant stress (Cregg et al., 2004; Ritchie and Landis, 2005). In A. lasiocarpa, $\mathrm{F}_{\mathrm{v}} / \mathrm{F}_{\mathrm{m}}$ declined only slightly as soil $\mathrm{pH}$ approached 7.0, while $\mathrm{F}_{\mathrm{v}} / \mathrm{F}_{\mathrm{m}}$ declined rapidly in $A$. sibirica and $A$. borisii regis Mattf. (Cregg et al., 2004). This suggests $A$. lasiocarpa is more tolerant of higher $\mathrm{pH}$ soils (soil $\mathrm{pH}>6.0$ ). Soils low in $\mathrm{pH}$ are often high in humus and clay (Miller and Donahue, 1995). However, in its native range, $A$. lasiocarpa is adapted to grow well in alluvial floodplains and at high elevations in sand and silt loams (Alexander et al., 1990). Abies concolor is tolerant of a wide range of soil $\mathrm{pH}$ and grows best on sandy-loam to clay-loam soils (Laacke, 1990), while A. amabilis grows best in soils

Table 3. Reported ideal soil pH ranges of various Abies species and hybrids.

\begin{tabular}{lccll}
\hline & & & Ideal soil & \\
Species & Section $^{z}$ & Subsection $^{z}$ & pH range & Source \\
\hline amabilis & Amabilis & & $3.3-4.0$ & Crawford and Oliver, 1990 \\
balsamea & Balsamea & Laterales & $5.1-6.0$ & Johnston, 1986 \\
balsamea & Balsamea & Laterales & $6.5-7.0$ & Bakuzis and Hansen, 1965 \\
boriss regis & Abies & & $3.5-4.0$ & Cregg et al., 2004 \\
chensiensis & Momi & Holophyllae & $4.0-6.0$ & Jones, 2005 \\
fraseri & Balsamea & Medianae & $3.5-4.2$ & Beck, 1990 \\
fraseri & Balsamea & Medianae & $4.2-4.5$ & Bryan et al., 1989 \\
homolepis & Momi & Homolepides & $4.0-5.0$ & Jones, 2005 \\
koreana $x$ balsamea & Hybrid & & $4.0-6.0$ & Jones, 2005 \\
koreana $x$ veitchii & Hybrid & & $4.0-6.0$ & Jones, 2005 \\
lasiocarpa & Balsamea & Laterales & $3.5-6.5$ & Cregg et al., 2004 \\
lasiocarpa & Balsamea & Laterales & $4.0-6.0$ & Jones, 2005 \\
lasiocarpa & Balsamea & Laterales & $4.5-5.9$ & Alexander et al., 1990 \\
lasiocarpa var. arizonica & Balsamea & Laterales & $4.0-6.5$ & Jones, 2005 \\
nephrolepis & Balsamea & Medianae & $4.0-6.5$ & Jones, 2005 \\
procera & Nobilis & & $4.0-5.5$ & Jones, 2005 \\
sachalinensis & Balsaema & Medianae & $3.0-4.5$ & Cregg et al., 2004 \\
sibirica & Balsamea & Laterales & $3.5-4.5$ & Cregg et al., 2004 \\
veitchii & Balsamea & Medianae & $3.5-6.0$ & Cregg et al., 2004 \\
\hline AA & & &
\end{tabular}

${ }^{\mathrm{z} A c c o r d i n g ~ t o ~ F a r j o n, ~} 1990$.

Table 4. Abies species reported to meet several selective factors necessary for introduction into the landscape and Christmas Tree industries in the upper midwestern U.S. ${ }^{2}$

\begin{tabular}{|c|c|c|c|c|c|}
\hline Species & $\begin{array}{l}\text { Adequate } \\
\text { cold } \\
\text { hardiness }^{y}\end{array}$ & $\begin{array}{c}\text { Drought } \\
\text { tolerant }\end{array}$ & $\begin{array}{c}\text { Tolerant } \\
\text { of low } \\
\text { soil } \mathrm{pH}^{\mathrm{x}}\end{array}$ & $\begin{array}{l}\text { Tolerant } \\
\text { of high } \\
\text { soil } \mathrm{pH}^{\mathrm{w}}\end{array}$ & $\begin{array}{c}\text { Late } \\
\text { budbreak }\end{array}$ \\
\hline amabilis & $\mathrm{X}$ & & $\mathrm{X}$ & & NA \\
\hline balsamea & $\mathrm{X}$ & $\mathrm{X}$ & & $\mathrm{X}$ & \\
\hline fraseri & $\mathrm{X}$ & & $\mathrm{X}$ & & $\mathrm{X}$ \\
\hline homolepis & $\mathrm{X}$ & NA & $\mathrm{X}$ & & $\mathrm{X}$ \\
\hline koreana & $\mathrm{X}$ & $\mathrm{X}$ & NA & NA & $\mathrm{X}$ \\
\hline lasiocarpa & $\mathrm{X}$ & & & $\mathrm{X}$ & \\
\hline las. var. arizonica & $\mathrm{X}$ & & & $\mathrm{X}$ & \\
\hline nephrolepis & $\mathrm{X}$ & & $\mathrm{X}$ & $\mathrm{X}$ & \\
\hline procera & $\mathrm{X}$ & NA & $\mathrm{X}$ & & $\mathrm{X}$ \\
\hline sachalinensis & $\mathrm{X}$ & NA & $\mathrm{X}$ & & \\
\hline sibirica & $\mathrm{X}$ & NA & $\mathrm{X}$ & & \\
\hline veitchii & $\mathrm{X}$ & NA & $\mathrm{X}$ & $\mathrm{X}$ & $\mathrm{X}$ \\
\hline
\end{tabular}

${ }^{2}$ States surrounding the Great Lakes (USDA plant hardiness zones 3 to 6 ).

y Tolerant of temperatures less than $-40^{\circ} \mathrm{C}$.

${ }^{\mathrm{x}}$ Soil $\mathrm{pH}<5.0$.

"Soil $\mathrm{pH} \geq 6.0$. with soil $\mathrm{pH}$ ranging between 3.3 and 4.0 and thick in organic matter (Crawford and Oliver, 1990). This suggests species and trees naturally growing in soils with more sand or silt would be more adapted to higher soil $\mathrm{pH}$ conditions.

The ideal soil $\mathrm{pH}$ range varies among species (Table 3); however, the taxonomic classification reveals some general trends. For example, species assigned to section Balsamea generally are more tolerant of soil with $\mathrm{pH}>6.0$, although some exceptions do exist (A. sibirica, A. sachalinensis, and A. fraseri). Conversely, species assigned to the section Momi are less tolerant of soil $\mathrm{pH}>6.0$. In future introduction, targeting species related to species with known tolerance to soil $\mathrm{pH}>6.0$ may result in identifying species tolerant of high $\mathrm{pH}$ soils; although, some exceptions will exist.

In summary, using chlorophyll fluorescence and foliar nutrient analysis may help identify species and trees tolerant of high $\mathrm{pH}$ soils. Species and trees of provenances growing in soils high in sand and silt may be more tolerant of high pH soils. The use of taxonomic relationships could be helpful to identify species closely related to species with known tolerance of high soil $\mathrm{pH}$.

\section{Recommendations}

This literature review has focused on identifying Abies spp. with adequate cold hardiness, late budbreak, drought tolerance, and tolerance of varying soil $\mathrm{pH}$ levels. These selection factors are necessary in future species introductions in the upper midwestern U.S. It is important to match plants possessing necessary adaptive characteristics with existing site conditions. Therefore, multiple screening factors should be met when identifying species or trees for future introduction (Table 4). For example, $A$. veitchii has adequate cold hardiness, breaks bud in late spring, and is tolerant of high soil $\mathrm{pH}(\mathrm{pH}>6.0)$ making it a strong candidate for introduction into the landscape industry in the upper midwestern U.S. Conversely, species or trees not meeting multiple screening factors should be given careful consideration before being introduced to the trade. For example, $A$. sachalinensis has adequate cold hardiness but is not tolerant of soils with $\mathrm{pH}>6.0$ and is prone to early budbreak. As a result, $A$. sachalinensis should be carefully evaluated to identify trees from provenances meeting multiple screening factors before being introduced to the trade.

\section{Literature Cited}

Alexander, R.R., R.C. Shearer, and W.D. Shepperd. 1990. Subalpine fir. In: R.M. Burns and B.H. Honkala (tech coords.). Silvics of North America: 1. Conifers. USDA For. Serv. Agr. Hdbk. 654.

Bakuzis, E.V. and H.L. Hansen. 1965. Balsam fir-a monographic review. Univ. Minn. Press, Minneapolis.

Beck, D. E. 1990. Fraser fir. In: R.M. Burns and B.H. Honkala (tech coords.). Silvics of North America: 1. Conifers. USDA For. Serv. Agr. Hdbk. 654.

Berry, J. and O. Björkman. 1980. Photosynthetic response and adaptation to temperature in higher plants. Annu. Rev. Plant Physiol. 31:491-543. 
Björkman, O. and B. Demming. 1987. Photo yield of $\mathrm{O}_{2}$ evolution and chlorophyll fluorescence characteristics at $77 \mathrm{~K}$ among vascular plants of diverse origins. Planta. 170:489-504

Brown, J.H. 1983. A “new” fir for Ohio Christmas tree plantings? Ohio Rpt. 68:51-54.

Brown, J.H. 2000. Survival and growth of trees of a Canaan Valley, West Virginia, seed source in relation to varying soil/site conditions. Ohio State Univ. Ext. Spec. Circ. 175-00.

Bruns, P.E. 1973. Cultural practices, fertilizing and foliar analysis of balsam fir Christmas trees. N.H. Agr. Expt. Sta. (Durham) Bul. 501.

Bryan, J.A., J.R. Seiler, and R.D. Wright. 1989. Influence of growth medium $\mathrm{pH}$ on the growth of container-grown fraser fir seedlings. J. Environ. Hort. 7:62-64

Buchmann, N., T.M. Hinckley, and J.R. Ehleringer. 1998. Carbon isotope dynamics in Abies amabilis stands in the Cascades. Can. J. For. Res. 28:808-819

Campbell, R.K. and A.I. Sugano. 1979. Genecology of bud-burst phenology in Douglas-fir: Response to flushing temperature and chilling. Bot. Gaz. 140:223-231.

Coleman, M.D., T.M. Hinckley, G. McNaughton, and B.A. Smit. 1992. Root cold hardiness and native distribution of subalpine conifers. Can. J. For. Res. 22: 932-938.

Crawford, P.D. and C.D. Oliver. 1990. Pacific silver fir. In: R.M. Burns and B.H. Honkala (tech coords.). Silvics of North America: 1. Conifers. USDA For. Serv. Agr. Hdbk. 654.

Cregg, B.M. 1994. Caron allocation, gas exchange, and needle morphology of Pinus ponderosa genotypes known to differ in growth and survival under imposed drought. Tree Physiol. 14:883-898.

Cregg, B.M. 2004. Selecting trees for improving drought tolerance: Theoretical and practical considerations. Acta Hort. 630:147-156.

Cregg, B.M., M.W. Duck, C.M., Rios, D.B. Rowe, and M.R. Koelling. 2004. Chlorophyll fluorescence and needle chlorophyll concentration of fir (Abies sp.) seedlings in response to $\mathrm{pH}$. HortScience 39:1121-1125.

Critchfield, W.B. 1988. Hybridization of the California firs. For. Sci. 34(1):139-51.

Eiga, S. and A. Sakai. 1984. Altitudinal variation in freezing resistance of Saghalien fir (Abies sachalinensis). Can. J. Bot. 62:156-160.

Eiga, S. and A. Sakai. 1987. Regional variation in cold hardiness of Sakhalin fir (Abies sachalinensis Mast.) in Hokkaido, Japan. In: P.H. Li (ed.). Plant cold hardiness. Liss, New York.

Farjon, A. 1990. Pinaceae drawings and descriptions of the genera Abies, Cedrus, Psudolarix, Keteleeria, Nothotsuga, Tsuga, Cathaya, Pseudotsuga, Larix, and Picea. Champaign, Ill.

Farquhar, G.D., J.R. Ehleringer, and K.T. Hubick. 1989. Carbon isotope discrimination and photosynthesis. Annu. Rev. Plant Physiol. Plant Mol. Biol. 40:503-537.

Foiles, M.W., R.T. Graham, and D.F. Olson, Jr. 1990. Grand fir. In: R.M. Burns and B.H. Honkala (tech coords.). Silvics of North America: 1. Conifers. USDA For. Serv. Agr. Hdbk. 654.

Franklin, J.F. 1990. Noble fir. In: R.M. Burns and B.H. Honkala (tech coords.). Silvics of North America: 1. Conifers. USDA For. Serv. Agr. Hdbk. 654.

Fryer, J.H. and F.T. Ledig. 1972. Microevolution of the photosynthetic temperature optimum in relation to the elevational complex gradient. Can. J. Bot. 50:1231-1235.

Gordon-Kamm, W.J. 1980. Freezing tolerance of several conifers in a western Washington forest community. MS thesis. W. Wash. Univ.,
Bellingham,

Guehl, J.M. and G. Aussenac. 1987. Photosynthesis decrease and stomatal control of gas exchange in Abies alba Mill. in response to vapor pressure difference. Plant Physiol. 83:316-322.

Guehl, J.M, G. Aussenac, J. Bouachrine, R. Zimmerman, J.M. Pennes, A. Ferhi, and P. Grieu. 1991. Sensitivity of leaf gas exchange to atmospheric drought, soil drought, and water-use efficiency in some Mediterranean Abies species. Can. J. For. Res. 21:1507-1515.

Guehl, J.M., J. Bouachrine, R. Zimmermann, and E. Dreyer. 1989. Responses of photosynthesis and stomatal conductance to atmospheric humidity in some Mediterranean Abies species. Ann. Sci. For. 46(S):401s-405s

Hallgren, S.W. and J.A. Helms. 1988. Control of height growth components in seedlings of California red and white fir by seed sources and water stress. Can. J. For. Res. 18:521-529.

Hansen, J.K. and J.B. Larsen, 2004. European silver fir (Abies alba Mill.) provenances for Calabria southern Italy: 15-year results from Danish provenance field trials. Euro. J. For. Res. 123:127-138.

Hansen, O.K., U. B. Nielsen, Ø.M. Edvardsen, B. Skúlason, and J. Skage. 2004. Nordic provenance trials with Abies lasiocarpa and Abies lasiocarpa var. arizonica: three-year results. Scand. J. For Res. 19:112-126.

Hiltbrunner, E. and W. Flückiger. 1996. Manganese deficiency of silver fir trees (Abies alba) at a reforested site in the Jura mountains, Switzerland: aspects of cause and effect. Tree Physiol. 16:963-975.

Howe, G.T., S.N. Aitken, D.B. Neale, K.D., Jermstad, N.C. Wheeler, and T.H.H. Chen. 2003. From genotype to phenotype: unraveling the complexities of cold adaptation in forest trees. Can. J. Bot. 81:1247-1266.

Illinois Department of Natural Resources. 2005. Midwest regional climate center. Champaign, Ill. 18 Oct 2005. http://mcc.sws.uiuc.edu/.

Isoda, K., S. Shiraishi, S. Watanabe, and K. Kitamura. 2000. Molecular evidence of natural hybridization between Abies veitchii and $A$. homolepis (Pinaceae) revealed by chloroplast, mitochondrial and nuclear DNA markers. Mol. Ecol. 9:1965-1973.

Jacobs, B.F., C.R. Werth, and S.I. Guttman. 1984 Genetic relationships in Abies of eastern United States: an electrophoretic study. Can. J. Bot. 62:609-616.

Johnston, William F. 1986. Manager's handbook for balsam fir in the north central states. USDA For. Serv. Gen. Tech. Rpt. NC-111. N. Central For. Exper. Sta., St. Paul, Minn.

Jones, G.E., 2005. Interspecific variation in adaptive traits of true firs (Abies spp.). MS thesis. Mich. State Univ., East Lansing.

Jones, G.E. and B.M. Cregg. 2006. Budbreak and winter injury in exotic firs (Abies spp.). HortScience 41:143-148.

Khalil, N., C. Leyval, M. Bonneau, and B. Guillet. 1989. Influence du type de nutrition azotée sur le déclenchement de la chlorose du sapin de Nordmann (Abies nordmanniana, Spach, 1842) (Summary in English). Ann. Sci. For. 46:325-343.

Klaehn, F.U. and J.A. Winieski. 1962. Interspecific hybridization in the genus Abies. Silvae Genet. 11:130-140.

Kohyama, T. 1984. Regeneration and coexistence of two Abies species dominating subalpine forests in central Japan. Oecologia 62:156-161.

Laacke, R.J. 1990a. California red fir. In: R.M. Burns and B.H. Honkala (tech coords.). Silvics of North America: 1. Conifers. USDA For. Serv.
Agr. Hdbk. 654.

Laacke, R.J. 1990b. White fir. In: R.M. Burns and B.H. Honkala (tech coords.). Silvics of North America: 1. Conifers. USDA For. Serv. Agr. Hdbk. 654.

Larsen, J.B. and F. Mekic. 1991. The geographic variation in European silver fir(Abies alba Mill.). Silvae Genet. 40:188-198.

Lavigne, M.B., C.H.A. Little, and J.E. Major. 2001. Increasing the sink:source balance enhances photosynthetic rate of 1 -year-old balsam fir foliage by increasing allocation of mineral nutrients. Tree Physiol. 21:417-426.

Liu, T.S. 1971. A monograph of the genus Abies. Taipei, Taiwan.

Lucas, R.E. and J.F. Davis. 1961. Relationships between $\mathrm{pH}$ values of organic soils and availabilities of 12 plant nutrients. Soil Sci. 92:177-182.

Martin, T.A., T.M.Hinckley, F.C. Meinzer, and D.G. Sprugel. 1999. Boundary layer conductance, leaf temperature and transpiration of Abies amabilis branches. Tree Physiol. 19:435-443.

Masle, J. and G.D. Farquhar. 1988. Effects of soil strength on the relation of water-use efficiency and growth to carbon isotope discrimination in wheat seedlings. Plant Physiol. 86:32-38.

McCullough, D.G., S.A. Katovich, D.L. Mahr, D.D. Neumann, C.S. Sadof, and M.J. Raupp. 1999. Biological control of insect pests in forested ecosystems: a manual for foresters, Christmas tree growers and landscapers. Mich. State Ext. Bul. E-2679.

McCullough, D.G., S.A. Katovich, M.E. Ostry, and J. Cummings-Carlson. 1998. Christmas tree pest manual. 2nd ed. Mich. State Ext. Bul. E-2676.

Miller, R.W. and R.L. Donahue. 1995. Soils in our environment. 7th ed. Prentice-Hall, Englewood Cliffs, N.J.

Moore, J.A., P.G. Mika, T.M. Shaw, and M.I. Garrison-Johnston. 2004. Foliar nutrient characteristics of four conifer species in the interior northwest United States. W. J. Appl. For. 19:13-24.

Myers Jr., O. and F.H. Bormann. 1963. Phenotypic variation in Abies balsamea in response to altitudinal and geographic gradients. Ecology 44:429-436.

Nicholls, T.H. and M.A. Palmer. 1985. Christmas tree winter injury in the lake states. Amer. Christmas tree J. 29:21-25.

Owston, P.W. and T.T. Kozlowski. 1981. Growth and cold hardiness of container grown Douglas-fir, noble fir, and Sitka spruce seedlings in simulated greenhouse regimes. Can. J. For. Res. $11: 465-474$.

Parducci, L., A.E. Szmidt, A. Madaghiele, M. Anzidei, and G. G. Vendramin. 2001. Genetic variation at chloroplast microsatellites (cpSSRs) in Abies nebrodensis (Lojac.) Mattei and three neighboring Abies Species. Theor. Appl. Genet. 102:733-740.

Perry, T.O. and W.C. Wu. 1960. Genetic variation in the winter chilling requirement for date of dormancy break for Acer rubrum. Ecology. 41:790-794.

Peterson, D.W., D.L. Peterson, and G.J. Ettl. 2002. Growth responses of subalpine fir to climatic variability in the Pacific Northwest. Can. J. For. Res. 32:1503-1517.

Piñol, J and A. Sala. 2000. Ecological implications of xylem cavitation for several Pinaceae in the Pacific Northern USA. Funct. Ecol. 14:538-545.

Ritchie, G. and T.D. Landis. 2005. Seedling quality tests: chlorophyll fluorescence. For. Nurs. Notes. Publ. R6-CP-TP-11-04. (Winter):12-16.

Ritchie, G.A. 2003. Root physiology and phenology: the key to transplanting success. In: L.E. Riley, R.K. Dumroese, and T.D. Landis (tech. coords.). 
National proceedings: Forest and conservation nursery associations - 2002. USDA For. Serv., Rocky Mountain research station, Ogden, Utah. Proc. RMRS-P-28: 98-104.

Robakowski, P., P. Montpied, and E. Dreyer. 2002. Temperature response of photosynthesis of silver fir (Abies alba Mill.) seedlings. Ann. For. Sci. 59:163-170.

Rothstein, R.E. and N. Lisuzzo. 2003. Optimal nutrition of fraser fir Christmas trees in Michigan, $\mathrm{p}$. 19-21. In: D. Brown-Rytlewski and J. O'Donnell (eds.). Nursery, landscape and Christmas tree research projects and educational programs. Mich. State Univ. Ext., East Lansing.

Rushforth, K.D. 1987. Conifers. Christopher Helm, London.

Sakai, A. 1982. Extraorgan freezing of primordial shoots of winter buds of Conifers, p. 199-209. In: P.H. Li and A. Sakai (eds.). Plant cold hardiness and freezing stress mechanisms and crop implications. vol 2. Academic Press, New York.

Sakata, M. and K. Suzuki. 2000. Evaluating possible causes for the decline of Japanese fir (Abies firma) forests based on $\delta^{13} \mathrm{C}$ records of annual growth rings. Environ. Sci. Technol. 34:373-376.

Sala,A., E. V. Carey, R.E. Kaene, and R.M. Callaway. 2001. Water use by whitebark pine and subalpine fir: potential consequences of fire exclusion in the northern Rocky Mountains. Tree Physiol. 21:717-725.
Scholz, F. and B.R. Stephan. 1982. Growth and reaction to drought of 43 Abies grandis provenances in a greenhouse study. Silvae Genet. 31:27-35.

Smith, W.K. 1980. Importance of aerodynamic resistance to water use efficiency in three conifers under field conditions. Plant Physiol. 65:132-135.

Smith, W.K. and G.A. Carter. 1988. Shoot structure effects on needle temperatures and photosynthesis in conifers. Amer. J. Bot. 75:496-500.

Strimbeck, G.R., Schaberg, P.G., DeHayes, D.H., Shane, J.B., and G.J. Hawley. 1995. Midwinter dehardening of montaine red spruce during a natural thaw. Can. J. For. Res. 25:2040-2044.

Sutinen, M.L., R. Arora, M. Wisniewski, E. Ashworth, R. Strimbeck, and J. Palta. 2001. Mechanisms of frost survival and freeze-damage in nature, p. 89-120. In: F.J. Bigras and S.J. Colombo (eds.). Conifer cold hardiness. Kluwer Academic Publ., Norwell, Mass.

U.S. Department of Agriculture. 1990. Plant hardiness zone map. USDA Misc. Publ. 1475.

U.S. Department of Agriculture. 1986. Soil survey of Kent County, Mich.

U.S. Department of Agriculture. 2001. Nursery crops 2000 summary. 13 Feb. 2005. http://usda. mannlib.cornell.edu/reports/nassr/other/nursery/nurser01.pdf.

U.S. Department of Agriculture. 2003. Soil survey of Forest County, Wis.

van der Kamp, B.J. and J. Worrall. 1990. An unusual case of winter bud damage in British Columbia interior conifers. Can. J. For. Res. 20:1640-1647.

Webster, R., A. Rigling, and L. Walthert. 1996. An analysis of crown conditions of Picea, Fagus and Abies in relation to environment in Switzerland. Forestry 69:347-355.

Weiser, C.J. 1970. Cold resistance and injury in woody plants. Science 169:1269-1278.

White, M.A. and G.E. Host. 2002. An assessment of potential evapotranspiration for the Northern Lake States. Natural Resources Research Institiute. Duluth, Minn. 19 Oct 2005. http://www. nrri.umn.edu/gla/pet.htm.

Worrall, J. 1983. Temperature-Bud-burst relationships in amabilis and subalpine fir provenance tests replicated at different elevations. Silvae Genet. 32:203-209.

Xiaohong, L., Q. Dahe, S. Xuemei, C. Tuo, and R. Jiawen. 2003. Climatic significance of stable carbon isotope in tree rings of Abies spectabilis in southeastern Tibet. Chinese Sci. Bul. 48:2000-2004.

Xie, C.Y. and C.C. Ying. 1993. Geographic variation of grand fir (Abies grandis) in the Pacific coast region: 10-year results from a provenance trial. Can. J. For. Res. 23:1065-1072. 